\title{
"The association between cognitive biases and the quality of strategic decision making: Evidence from Jordanian banks"
}

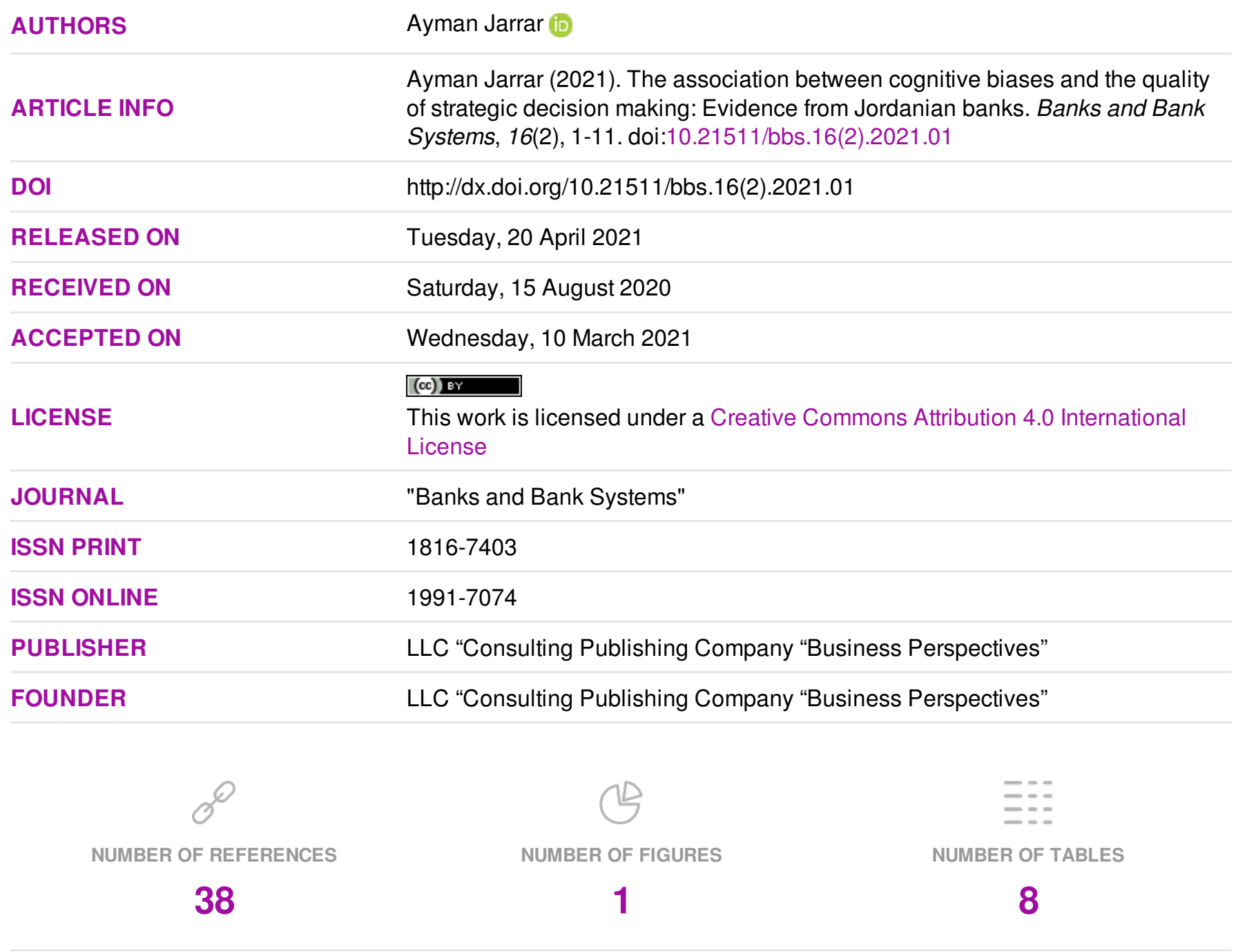

(C) The author(s) 2021. This publication is an open access article. 


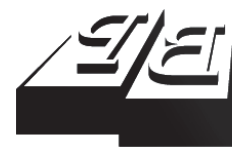

BUSINESS PERSPECTIVES

(O)

LLC "CPC "Business Perspectives" Hryhorii Skovoroda lane, 10, Sumy, 40022, Ukraine www.businessperspectives.org

Received on: $15^{\text {th }}$ of August, 2020 Accepted on: $10^{\text {th }}$ of March, 2021 Published on: $20^{\text {th }}$ of April, 2021

() Ayman Jarrar, 2021

Ayman Jarrar, PhD. Student, Business and Finance School, Management Department, The World Islamic Sciences and Education University, Jordan.

\section{THE ASSOCIATION BETWEEN COGNITIVE BIASES AND THE QUALITY OF STRATEGIC DECISION MAKING: EVIDENCE FROM JORDANIAN BANKS}

\begin{abstract}
Excellence in strategic decision making is the driving force behind successful strategy adoption and implementation. However, it is becoming more and more complex as businesses emerge in unpredictable environments and conditions. The main objective of this study is to investigate the impact of cognitive bias and its dimensions (the illusion of control, prior hypothesis bias, escalating commitment bias and representativeness, and availability bias) on strategic decision making. In terms of methodology, the study used a random sampling technique. The study applied a survey as a research tool distributed among 138 bankers (employees at the managerial level) in managerial and administrative positions.
\end{abstract}

Further, descriptive analysis and regression analysis were used to analyze the data and test hypotheses. The results show a positive and significant effect of the illusion of control and representativeness. The results show that the illusion of control, prior hypothesis bias, escalating commitment bias and representativeness, and availability bias significantly impact the strategic decision-making in Jordanian banks. It is concluded that the null hypothesis will be accepted and, therefore, the alternative hypothesis will be rejected based on the significant levels for the primary and secondary hypotheses.

The factors of the escalating commitment bias, the availability bias, and the reasoning by analogy were not significant. Finally, the study recommends developing more literature on integrating psychology and discrimination and applying the research to different industries and managerial levels.

Keywords

bias in decisions, top management, Jordan, organizational changes, a tendency

JEL Classification $\quad$ L10, M10, M14

\section{INTRODUCTION}

It cannot be denied that any organization strives to gain a sustainable competitive advantage and services excellence. Such goals require sound and rational justification. Besides, they need a comprehensive analysis of both internal and external environments based on knowledge to develop resources and capabilities and craft the best strategies (Sharma et al., 2014; Bonn \& Fisher, 2011).

In the last few decades, the observers witnessed rapid changes in the economy, technology and managerial perspectives due to population growth, digitalization, inflation, changes in a social lifestyle, risen consumptions, but scarce resources. Consequently, such changes in the business environment force strategic managers to make many strategic decisions daily, even if they are not intended to do so. In other words, explicitly avoiding a decision is to decide (Nooraie, 2012). 
As a minority believe, distinction in strategic decision making is the driver towards successful strategy adoption and implementation. However, it is becoming much complex as businesses emerge in unstable environments and conditions. It is necessary to distinguish between ordinary decisions and strategic ones; routine decisions are more likely in the short term, while strategic decisions have long-term implications. Moreover, they usually have shared characteristics; specifically, they are unique, directive and consequential (Wheelen et al., 2010).

Strategic decision making is a complex process with specific characteristics and can be approached in several modes. Regardless of manners and attributes, any deviation in these directions will cost the organizations the loss of their position, market share, customers, image profitability ratios, and sometimes their existence in the market; Nokia is an excellent example in this context.

As a result of psychological attributes, pressures, and uncertainty, decision-makers may not follow rational thinking. Instead, they follow specific heuristics, which arises from different cognitive biases within the human makeup. These biases can have the upper hand in deciding the fall or rise of the organization.

Mintzberg (1973), as one of the leaders of the strategic sciences, demonstrated that strategic decision-making commits to three different approaches such as entrepreneurial, planning and adaptive modes. In support of his contention, Quinn (1978) appended the logical incrementalism mode as the fourth mode. Nevertheless, the experiments and many strategic and psychological research acknowledged the fact that particular limitations in the human's cognitive capabilities influence the rationality of decision making. Hence, strategic decision making has typically a tendency towards relying on some heuristics that helps in reducing the uncertainty. On the other hand, such heuristics sometimes lead to significant systematic errors and poor decisions (Hill et al., 2014).

Business environments, considering the presented arguments, are too fast. Likewise, the changes in their conditions result in endless challenges and unfamiliar problems introduced to the management. These dramatic changes require executives who are already fearful and anxious in an unpredictable environment to make more choices at a more accelerated pace. Therefore, this study investigates the association between cognitive bias and the quality of strategic decision-making in Jordanian banks.

Therefore, understanding these biases can reduce systemic errors in strategic decision-making and avoid financial and non-financial consequences of such improper strategic direction. Hence, this study tries to answer the question, "What is the association between cognitive bias and the quality of strategic decision making?"

The value of this study, from a practical viewpoint, is to understand the effect of cognitive bias on strategic decision making. It will also help analysts and strategic frames evaluate how well-established organizations might fall, even though they are well-positioned in the market, and that resources and capabilities are no longer enough alone to guide the destiny of organizations. Therefore, they will focus on intensifying strategic decision-making and countering cognitive bias in decision-making toward being more rational, logical, realistic, objective, and based on the extensive evaluation. This is a crucial point, as it will reduce the gaps in the academic literature that correlates the behaviour, physiology and management at the executive and management levels, as this academic field lacks papers and adequate knowledge following the instructions of AlKhars et al. (2019) and Nouri et al. (2018).

According to the above literature, the main objective of this study is to ascertain the association between the prior hypothesis bias, escalating commitment and illusion of control, and the quality of strategic decision making. Consequently, it will provide recommendations on how irrationality and cognitive biases and sustained success and superior organizational performance influence the quality of strategic decision-making. 


\section{LITERATURE REVIEW}

Since research in strategic decision making and strategic management, in general, is highly appreciated, the literature on the association between cognitive bias and strategic decision making in banks is hardly available. Nevertheless, precious work on variables, in general, forms the basis of current dissertation research. For example, AlKhars et al. (2019) tackled the influence of representativeness heuristics on different cognitive biases in operational management, considering two covariates to the study, namely, gender and risk-taking behaviour. As for the methodology, the researcher experimented and administered a survey instrument to a control group (50\% of the sample) to identify the impact of learning as a de-biasing technique on reducing the bias in decision making. The study sample entailed 302 undergraduates and graduated operational management at North Texas University. The logistic regression analysis was used to analyze data. AlKhars et al.'s (2019) result pointed out that training and learning are precious in reducing biased decision. They suggested future research to reduce the limitation by expanding the study sample to enhance the generalizability.

Nouri et al. (2018) studied the impact of the biases in entrepreneurs' decisions on marketing behaviour in small business. They operationalized the heuristics and biases into dimensions, namely, the availability, representativeness, escalation of commitment and illusion of control heuristics. Nouri et al. (2018) adopted a qualitative method and conducted semi-structured interviews with 15 Iranian entrepreneurs working in the biotechnology field. The data was analyzed based on thematic analysis. The results indicated a significant impact of representativeness, escalation of commitment and illusion of control, and the quality of entrepreneur marketing behaviour on decision making. Accordingly, they recommended future work to extend the scope and investigate other industries and different countries other than Iran.

The impact of cognitive bias diversity on strategic decision making (measured as the illusion of control) and how such bias would limit the opportunities and the quality outcomes in a complicated environment is studied. In terms of methodology, the study adopted a vignette-based experi- ment investigation on 102 management students and used a pre-test and post-test control group design to ensure validity. Three groups were administered through a questionnaire to test their level of an illusion of control bias. The researchers applied the ANOVA analysis and non-parametric Kolmogorov-Smirnoff (K-S) test to examine the difference between the sampled control groups. The results showed a significant relationship between a high level of diversity in groups and a weaker level of an illusion of control bias (Meissner \& Wulf, 2017).

Bakar and Yi (2016) examined the impact of psychological and behavioural aspects on the Malaysian stock market's financial investors' decision-making process. The researchers adopted a questionnaire as a research instrument administered to a sample of 200 investors selected using convenience, quota, and snowball sampling methods. The data were analyzed using multiple regression analysis. The main findings showed that availability bias had a significant influence on investors' decisions. Also, it proved the moderating role of gender. Finally, the study recommends future research to extended the sample size to overcome the current limitations. Also, the researcher recommends investigating other behavioural biases that might affect the quality of decision making.

Murata et al. (2015) investigated how cognitive bias could distort the decision-making process and lead to an unpredictable negative outcome. The study adopted a quantitative approach based on conducted in-depth case analysis through a systematic approach for five significant cases where the illusion of control and availability bias, for example, were behind a distorted and unbalanced decision making that caused a catastrophic incidence. It was concluded that in addition to other human factors that might exist in the environment, identifying, recognizing, and lowering the probability of cognitive biases is necessary to minimize incidents and decision-making activities that lead to tremendous losses in resources. Murata et al. (2015) recommended that future research focus on analyzing how to avoid cognitive biases and set measures to make this feasible in organizations.

Xue et al. (2015) explored the role of cognitive bias in enhancing decision-making and risk behaviour. 
For the methodology, the study attained a sample of 137 decision-makers; they applied the regression analysis using SPSS for the data analysis. The study results pointed out that the risk perception related to the cognitive bias was positively associated with risk behaviour, which would enhance decision-making.

Cognitive and motivational biases influence the relevancy levels of the decisions. The researchers applied a risk analysis technique to distort analysis inputs that are challenging to correct. The study conclusions designate that the biases are less relevant to the decision making as they can be modernized using logic or decomposing the elicitation task (Montibeller \& Winterfeldt, 2015).

\subsection{Study hypotheses}

$\mathrm{HO}_{1}$ : There is no statistically significant impact of managerial cognitive bias at $p \leq 5 \%$ on strategic decision-making in Jordanian banks.

$\mathrm{HO}_{1-1}$ : There is no statistically significant impact of the illusion of control at $p \leq 5 \%$ on strategic decision-making in Jordanian banks.

$\mathrm{HO}_{1-2}:$ There is no statistically significant impact of escalating the commitment bias at $p \leq 5 \%$ on strategic decision-making in Jordanian banks.

$\mathrm{HO}_{1-3}:$ There is no statistically significant impact of the representativeness at $p \leq 5 \%$ on strategic decision-making in Jordanian banks.

$\mathrm{HO}_{1-4}:$ There is no statistically significant impact of the availability bias at $p \leq 5 \%$ on strategic decision-making in Jordanian banks.

$\mathrm{HO}_{1-5}:$ There is no statistically significant impact of the reasoning by analogy at $p \leq 5 \%$ on strategic decision-making in Jordanian banks.

\section{METHODOLOGY}

\subsection{Research design}

This study is considered as applied (empirical) research in nature. It is also considered as a pri- mary, initial and explanatory (causal relationship research) research according to its purpose. It is non-contrived since it is conducted out of any laboratory or controlled settings. Further, it is cross-sectional and not based on time-series data (one-time analysis).

This study used a deductive approach, as it adopts the theory based on the past literature and then collected the data to test the theory and either accept or reject the hypotheses based on the statistical analysis. The research will follow the quantitative causal research as it will depend on the numerical data and survey instrument to collect the research data. The analysis is in quantitative presentation as it follows the descriptive approach.

The population of this study entails managers from 13 Jordanian banks. The study followed a probabilistic random sampling method. According to Corder and Foreman $(2009$, p. 2$)$, a sample size of 100 will preserve the data representation and maintain the normality. For this study, the sample size is 138 respondents (bank employees). The survey was conducted online using Google Forms. The results were processed after conducting a filtration of all missing data and outliers using SPSS. The response rate was $38 \%$.

The variables of this study were measured using a survey instrument as follows:

The independent variable, cognitive bias, is operationalized into five out of 13 dimensions of the cognitive bias.

- The illusion of control and the items were adopted from Zuckerman (1996).

- Prior hypothesis bias and the items were adopted from Seppälä (2009).

- Escalating the commitment bias and items were adopted Seppälä (2009).

- Representativeness and items were adopted from Seppälä (2009).

Availability bias and items were adopted from Seppälä (2009). 


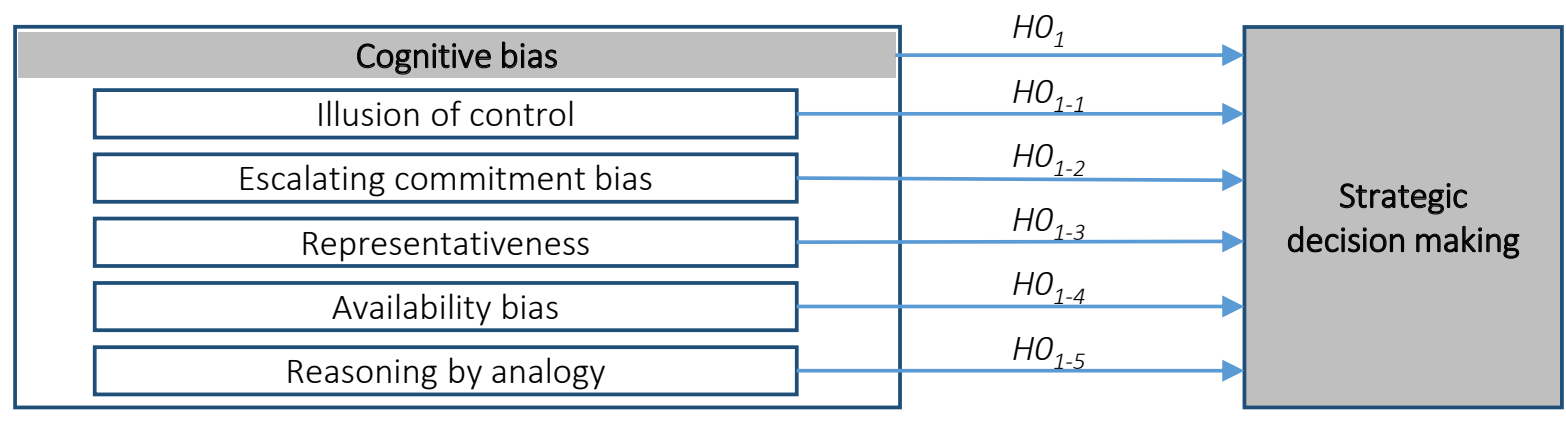

Figure 1. Study model

The dependent variable is strategic decision making, and the items were adopted from Montibeller and Winterfeldt (2015).

\section{RESULTS}

\subsection{Descriptive analysis}

The descriptive analysis presents the main characteristics of the sample members. It shows the percentages and the frequencies of the demographic data; besides, it illustrates the mean and the standard deviation values for the variables.

Table 1. Descriptive statistics - demographics

\begin{tabular}{|c|c|c|c|c|}
\hline \multicolumn{3}{|c|}{ Attributes } & \multirow{2}{*}{$\frac{\text { Frequency }}{113}$} & \multirow{2}{*}{$\frac{\%}{81.9 \%}$} \\
\hline Gender & 1 & Male & & \\
\hline Gender & 2 & Female & 25 & $18.1 \%$ \\
\hline \multirow{4}{*}{ Education level } & 1 & High school & 1 & $00.7 \%$ \\
\hline & 2 & Diploma & 12 & $08.7 \%$ \\
\hline & 3 & $\begin{array}{c}\text { Bachelor's } \\
\text { degree }\end{array}$ & 84 & $60.9 \%$ \\
\hline & 4 & Master's degree & 41 & $29.7 \%$ \\
\hline \multirow{5}{*}{ Age groups } & 1 & $\begin{array}{c}23 \text { - less than } 29 \\
\text { years }\end{array}$ & 11 & $08.0 \%$ \\
\hline & 2 & $\begin{array}{c}29 \text { less than } 35 \\
\text { years }\end{array}$ & 19 & $13.8 \%$ \\
\hline & 3 & $\begin{array}{c}35 \text { less than } 40 \\
\text { years }\end{array}$ & 77 & $55.8 \%$ \\
\hline & 4 & $\begin{array}{c}40 \text { less than } 50 \\
\text { years }\end{array}$ & 31 & $22.5 \%$ \\
\hline & 5 & $\begin{array}{c}\text { More than } 50 \\
\text { years. }\end{array}$ & 0 & $00.0 \%$ \\
\hline \multirow{4}{*}{$\begin{array}{l}\text { Years of } \\
\text { experience }\end{array}$} & 1 & $\begin{array}{c}0-\text { less than five } \\
\text { years }\end{array}$ & 10 & $07.2 \%$ \\
\hline & 2 & $\begin{array}{c}5-\text { less than ten } \\
\text { years }\end{array}$ & 13 & $09.4 \%$ \\
\hline & 3 & $\begin{array}{c}10-\text { less than } 15 \\
\text { years }\end{array}$ & 29 & $21.0 \%$ \\
\hline & 4 & $\begin{array}{c}15 \text { years and } \\
\text { more }\end{array}$ & 86 & $62.3 \%$ \\
\hline \multicolumn{3}{|l|}{ Total } & 138 & $100 \%$ \\
\hline
\end{tabular}

The descriptive analysis results show that most respondents are males with $81.9 \%$; this is justified due to the non-randomization in the sample. The majority of the model holds a Bachelor's degree with $60.9 \%$, followed by around $29 \%$ of Masters' degree holders. As the sample mainly consists of managers, the age groups of " 35 less than 40 years" and " 40 less than 50 years" were the dominant respondents with $55.8 \%$ and $22.5 \%$, respectively. The Years of experience variable shows that $62.3 \%$ of the sample members have more than 15 years of experience; these values confirm the sample validity as they are strategic people who can and hold the accountability to make strategic decisions.

Table 2 shows the mean and the standard deviation values of the internationalization readiness and the dynamic managerial capabilities. The mean value of the dynamic administrative capabilities is 4.004 , which means an agreement towards the existence of this dynamism in the managerial vision to sense, see and reconfigure the opportunities. The sensing ability has the highest mean value of 4.17. The result indicates that the respondents believe that their banks define new opportunities and new market segments; they also focus on customer needs and accumulate better knowledge about the market environment. However, the mean value is the least for internationalization readiness as a supportive sign of gaps in internationalization readiness. The standard deviation values are less than one and less than the mean values, which mirrors a harmony in the observations and raises the ability to generalize the assumption that banks have similar conditions. 
Table 2. Mean and standard deviation values

\begin{tabular}{l|c|c}
\hline \multicolumn{1}{c}{ Variables and dimensions } & Mean & Std. deviation \\
\hline Illusion of control & 3.070 & 0.633 \\
\hline Escalating commitment bias & 3.104 & 0.785 \\
\hline Representativeness & 3.449 & 0.697 \\
Availability bias & 3.957 & 0.744 \\
Cognitive bias & 3.320 & 0.431 \\
\hline Strategic decision making & 3.563 & 0.887 \\
\hline
\end{tabular}

\subsection{Hypothesis testing}

The objectives of this study are achieved by testing the model. The analysis used a single regression model that was used and analyzed to test the null hypothesis according to Tables 3 to 9, as shown below.

HO: There is no statistically significant impact of the managerial cognitive bias at $p \leq 5 \%$ on strategic decision-making in Jordanian banks.

The results of testing $\mathrm{HO}_{1}$ are shown in Table 3, which presents the regression model output for banks. It is observed from (variables entered/removed) the table that the method used is Enter; all variables were entered for analysis. It also shows that the independent variable is cognitive bias, and the dependent variable is strategic decision-making. The model summary table shows that the coefficient of correlation R equals 0.156 , which indicates a positive and robust relationship between cognitive bias and strategic decision-making. It is also found that the coefficient of determination R2 for the cognitive bias equals 0.024 , and that means that the cognitive bias has explained only $2.4 \%$ of variances of strategic decision-making. As for the ANOVA/Analysis of variance, it was found that the value of $\mathrm{F}$ was 3.375 at one degree of freedom with the p-value (Sig. $=0.068)$, which is more significant than $\mathrm{p} \leq 5 \%$, and this indicates that this model does not fit (non-significant regression). The Coefficients table shows that the value of $\mathrm{B}$ is 0.174 , with a standard deviation of 0.879 , and $\mathrm{Beta} / \beta$ is 0.320 . The value of $t$ is 1.837 at the significance level of 0.068 ; this confirms the non-significance of the coefficients at a confidence level of $\mathrm{p} \leq 5 \%$. Finally, it is concluded from the above analysis that the null hypothesis will be accepted and, therefore, the alternative hypothesis will be rejected.

\subsection{The sub-hypothesis}

\section{$\mathrm{HO}_{1-1}:$ There is no statistically significant impact of the illusion of control at $p \leq 5 \%$ on strategic decision-making in Jordanian banks.}

Testing $\mathrm{HO}_{1-1}$ and Table 4 (variables entered/removed) show that the method used is Enter; all variables were entered for analysis. The model summary table shows that the coefficient of correlation $\mathrm{R}$ equals 0.191 , indicating a positive medium relationship between the illusion of control and strategic decision-making. It was also found that coefficient of determination R2 equals 0.036 , which means that illusion of control has explained only $3.6 \%$ of the strategic decision-making variances. The ANOVA/Analysis of variance table

Table 3. Regression analysis for $\mathrm{HO}_{1}$

\begin{tabular}{|c|c|c|c|c|c|c|c|c|}
\hline \multicolumn{9}{|c|}{ Dependent variable } \\
\hline \multirow{2}{*}{$\begin{array}{l}\text { Strategic } \\
\text { decision-making }\end{array}$} & Independents & Hypothesis & T value & Sig. & $\beta$ & B & $\begin{array}{l}\text { Std. } \\
\text { error }\end{array}$ & Df \\
\hline & Managerial cognitive bias & $\mathrm{HO}_{1}$ & 1.837 & 0.07 & 0.32 & 0.17 & 0.87919 & 1 \\
\hline$R$ & \multicolumn{8}{|c|}{0.156} \\
\hline $\mathrm{R}^{2}$ & \multicolumn{8}{|c|}{0.024} \\
\hline $\mathrm{F}$ & \multicolumn{8}{|c|}{3.375} \\
\hline Sig. & \multicolumn{8}{|c|}{0.068} \\
\hline
\end{tabular}


Table 4. Regression analysis for $\mathrm{HO}_{1-1}$

\begin{tabular}{|c|c|c|c|c|c|c|c|c|}
\hline \multicolumn{9}{|c|}{ Dependent variable } \\
\hline $\begin{array}{l}\text { Strategic } \\
\text { decision-making }\end{array}$ & Independents & Hypothesis & $\mathrm{T}$ value & Sig. & $\beta$ & B & $\begin{array}{l}\text { Std. } \\
\text { error }\end{array}$ & Df \\
\hline & Illusion of control & $\mathrm{HO}_{1-1 \ldots}$ & 0.267 & 0.025 & 0.191 & 0.267 & 0.118 & 1 \\
\hline $\mathrm{R}$ & \multicolumn{8}{|c|}{0.156} \\
\hline$R^{2}$ & \multicolumn{8}{|c|}{0.024} \\
\hline $\mathrm{F}$ & \multicolumn{8}{|c|}{3.375} \\
\hline Sig. & \multicolumn{8}{|c|}{0.068} \\
\hline
\end{tabular}

shows that the value of $\mathrm{F}$ is 5.128 at one degree of freedom with p-value (Sig. $=0.025$ ), which is less than $\mathrm{p} \leq 5 \%$; this confirms that this model does fit (significant regression). The Coefficients table shows that the value of $B$ is 0.267 , with a standard deviation of 0.118 , and Beta/ $\beta$ is 0.191 . $t$ is 0.267 at the significance level of 0.025 , which confirms the significance of the coefficients at a confidence level of $p \leq 5 \%$. Thus, it is concluded that the null hypothesis will be rejected, and the alternative hypothesis will be rejected.

$\mathrm{HO}_{1-2}$ : There is no statistically significant impact of escalating the commitment bias at $p \leq 5 \%$ on strategic decision-making in Jordanian banks.

Testing $\mathrm{HO}_{1-2}$ and Table 5 (variables entered/removed) show that the method used is Enter. All variables were entered for analysis. The model summary table shows that the coefficient of correlation
$\mathrm{R}$ equals 0.148 , indicating a positive relationship between the escalating commitment and strategic decision-making. It was also found that the coefficient of determination R2 for escalating commitment equals 0.022; that means that escalating commitment has explained only $2.2 \%$ of variances of strategic decision-making. The ANOVA table shows that the value of $\mathrm{F}$ is 3.065 at one degree of freedom with a p-value (Sig. $=0.082$ ), which is not less than $p \leq 5 \%$; this confirms non-significant regression. It is also revealed that the value of $\mathrm{B}$ is 0.168 with a standard deviation of 0.069 and Bet $/ \beta$ is 0.148 ; the value of $t$ is 1.175 at the significance level of 0.000 , which confirms the non-significance of coefficients at a confidence level ( $p \leq 5 \%)$. Thus, the null hypothesis will be rejected, and the alternative hypothesis will be accepted.

\section{$\mathrm{HO}_{1-3}$ : There is no statistically significant impact of representativeness at $p \leq 5 \%$ on strategic de- cision-making in Jordanian banks.}

Table 5. Regression analysis for $\mathrm{HO}_{1-2}$

\begin{tabular}{|c|c|c|c|c|c|c|c|c|}
\hline \multicolumn{9}{|c|}{ Dependent variable } \\
\hline \multirow{2}{*}{$\begin{array}{l}\text { Strategic } \\
\text { decision-making }\end{array}$} & Independents & Hypothesis & T value & Sig. & $\beta$ & B & $\begin{array}{l}\text { Std. } \\
\text { error }\end{array}$ & Df \\
\hline & Escalating commitment & $\mathrm{HO}_{1-2}$ & 1.175 & 0.082 & 0.148 & 0.168 & 0.069 & 1 \\
\hline $\mathrm{R}$ & \multicolumn{8}{|c|}{0.148} \\
\hline$R^{2}$ & \multicolumn{8}{|c|}{0.022} \\
\hline $\mathrm{F}$ & \multicolumn{8}{|c|}{3.065} \\
\hline Sig. & \multicolumn{8}{|c|}{0.082} \\
\hline
\end{tabular}

Table 6. Regression analysis for $\mathrm{HO}_{1-3}$

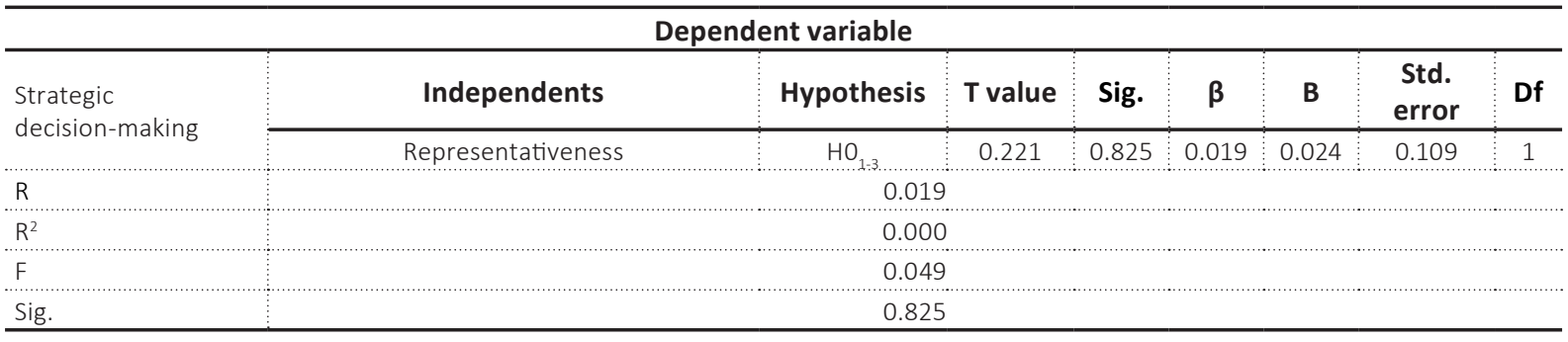


Table 7. Regression analysis for $\mathrm{HO}_{1-4}$

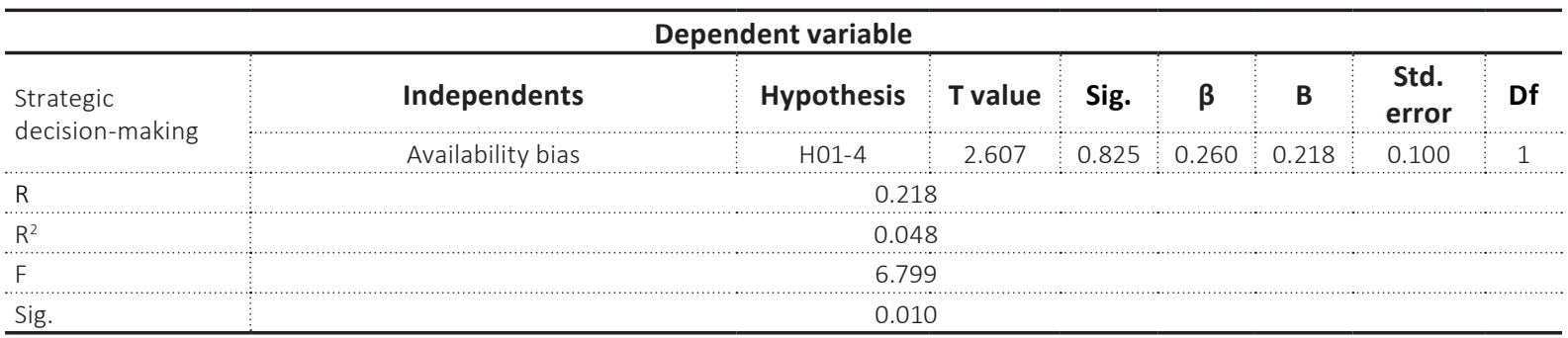

Testing $\mathrm{HO}_{1-3}$ and Table 6 (variables entered/removed) show that the method used is Enter; all variables were entered for analysis. The model summary table shows that the coefficient of correlation $\mathrm{R}$ equals 0.019 , indicating a positive correlation between representativeness and strategic decision-making. It is found that the coefficient of determination $\mathrm{R} 2$ equals 0.000 , which means that it explained nothing from the variances. From the ANOVA table, it is found that the value of $\mathrm{F}$ is 0.049 at one degree of freedom with $p$-value (Sig. = 0.825 ), which is less than $p \leq 5 \%$; it confirms that this model does not fit. It is also found from the Coefficients table that the value of $\mathrm{B}$ is 0.024 with a standard deviation of 0.109 ; Beta $/ \beta$ is 0.019 , and the value of $t$ is 0.221 at the significance level of Sig. $=0.825$, which confirms the significance of the coefficients at a confidence level $(\mathrm{p} \leq 5 \%)$. Thus, the alternative hypothesis will be rejected, and the null hypothesis is accepted.

$\mathrm{HO}_{1-4}:$ There is no statistically significant impact of the availability bias at $p \leq 5 \%$ on strategic decision-making in Jordanian banks.

Testing $\mathrm{HO}_{1-4}$ and Table 7 (variables entered/removed) show that the method used is Enter; all variables were entered for analysis. They also show that the Independent variable is availability bias, and the dependent variable is strategic decision-making. The model summary table shows that the coefficient of correlation $\mathrm{R}$ equals 0.218 , indicating a positive correlation between availability bias and strategic decision-making. It is found that the coefficient of determination R2 equals 0.048 , which means it explained $4.8 \%$ of variances. The ANOVA table shows that the value of $\mathrm{F}$ is 6.799 at one degree of freedom with $\mathrm{p}$-value (Sig. $=0.010$ ), which is less than $p \leq 5 \%$, and it confirms that this model does not fit. It is also found from the Coefficients table that the value of $B$ is 0.024 with a standard deviation of 0.109 and Beta/ $\beta$ is 0.019 . The value of $t$ is 0.221 at the significance level (Sig. $=0.825$ ), which confirms the significance of the coefficients at a confidence level ( $\mathrm{p} \leq 5 \%)$. Thus, the null hypothesis will be rejected, and the alternative hypothesis is accepted.

\section{$\mathrm{HO}_{1-5}:$ There is no statistically significant impact of the reasoning by analogy at $p \leq 5 \%$ on stra- tegic decision-making in Jordanian banks.}

Testing $\mathrm{HO}_{1-4}$ and Table 8 (variables entered/removed) show that the method used is Enter; all variables were entered for analysis. It also shows that the Independent variable is reasoning by analogy and the dependent variable is the strategic decision-making. The model summary table shows that the coefficient of correlation $\mathrm{R}$ equals 0.031 , indicating a positive correlation between the reasoning by analogy and strategic decision-making. It is found that the coefficient of determination

Table 8. Regression analysis for $\mathrm{HO}_{1-5}$

\begin{tabular}{|c|c|c|c|c|c|c|c|c|}
\hline \multicolumn{9}{|c|}{ Dependent variable } \\
\hline \multirow{2}{*}{$\begin{array}{l}\text { Strategic } \\
\text { decision-making }\end{array}$} & Independents & Hypothesis & T value & Sig. & $\beta$ & B & $\begin{array}{l}\text { Std. } \\
\text { error }\end{array}$ & Df \\
\hline & Reasoning by analogy & $\mathrm{HO}_{1-5}$ & -0.361 & 0.718 & -0.310 & -0.350 & 0.098 & 1 \\
\hline $\mathrm{R}$ & \multicolumn{8}{|c|}{0.031} \\
\hline $\mathrm{R}^{2}$ & \multicolumn{8}{|c|}{0.001} \\
\hline $\mathrm{F}$ & \multicolumn{8}{|c|}{0.131} \\
\hline Sig. & \multicolumn{8}{|c|}{0.718} \\
\hline
\end{tabular}


R2 equals 0.001, which means it explained almost nothing from the variances. The ANOVA table shows that the value of $\mathrm{F}$ is 0.131 at one degree of freedom with p-value (Sig. $=0.718$ ), which is less than $\mathrm{p} \leq 5 \%$; it confirms that this model does not fit. The Coefficients table also shows that the value of $B$ is 0.024 with a standard deviation of 0.109 , Beta / $\beta$ is -0.310 , and the value of $t$ is -0.361 at the significance level (Sig. $=0.718$ ), which confirms the significance of the coefficients at a confidence level ( $\mathrm{p} \leq 5 \%$ ). Thus, the null hypothesis will be accepted, and the alternative hypothesis is rejected.

\section{DISCUSSION}

The business environment has undergone radical shifts and transformation, which required strategic people to proactively respond to changes in the economy, digitalization, management, and strategic plans. Thus, resistance to changes and the penchant for old methods, procedures and problem solving will lead to variations in techniques and may cause leaving the market. Nokia and Kodak are examples of this situation. Therefore, changes in the business environment mandate strategic managers, even if they explicitly avoid deciding. The results show that the Independent variable is the illusion of control, and the dependent variable is strategic decision making. It also shows that the Independent variable is representativeness, and the dependent variable is strategic decision-making. Finally, it shows that the Independent variable is the escalating commitment, and the dependent variable is strategic decision-making.

Under restricted time and knowledge, humans make inferences about the universe. The heuristic-and-biases interpretation of human irrationality would lead one to conclude that humans are helpless in the face of real-world uncertainty (Gigerenzer \& Goldstein, 1996). However, the humanization of the strategic decision-making process is not without its problems (Chung \& McLarney, 1999). Over four decades ago, Tversky and Kahneman (1974) debated how people used "heuristics" to reduce decision-making complexities. Following that, the principle of bounded rationality acknowledges that humans have limited cognitive capacity. It casts doubt on the notion of a rational decision-maker who evaluates in light of available options/inputs, weighs their pros and cons, and then decides based on in-depth analysis of each piece of knowledge.

Heuristics are simplified rules of thumb for solving problems that follow the logic that is somewhat different from consequential reasoning. For a long time, it has been an inferior decision-making strategy that is a source of irrational decision-making. Recently, decision-making researchers have demonstrated that some heuristics are highly efficient and, in some application, can compete with intricate decision models to simplify judgmental operations. These heuristics are customarily very useful but often lead to severe and systemic errors.

\section{CONCLUSION}

The main objective of this study is to investigate the impact of cognitive bias on strategic decision making, which is realized as the illusion of control, escalating commitment bias, representativeness, availability bias, and reasoning by analogy. The study used a survey as a research tool that was distributed to 138 respondents. The results show a positive and significant effect of the illusion of control and representativeness. The study results show that analogy's escalating commitment bias, availability bias, and reasoning were not significant. They are in line with Meissner and Wulf (2017) and Nouri et al. (2018) and indicate a substantial impact of representativeness, escalation of commitment and the illusion of control on the quality of entrepreneur marketing behaviour and decision making.

\section{RECOMMENDATIONS}

The study provides the following recommendations: to analyze other variables such as personality treats and governance rules, as well as other factors, to preserve the transparency and the quality in strategic 
decision making; identify the limitations that prevent people from recognizing their cognitive biases; and finally, use a mixed quantitative and qualitative approach to get more complete results.

\section{AUTHOR CONTRIBUTIONS}

Data curation: Ayman Jarrar.

Formal analysis: Ayman Jarrar.

Investigation: Ayman Jarrar.

Methodology: Ayman Jarrar.

Project administration: Ayman Jarrar.

Software: Ayman Jarrar.

Writing - original draft: Ayman Jarrar.

Writing - reviewing \& editing: Ayman Jarrar.

\section{REFERENCES}

1. AlKhars, M., Evangelopoulos, N., Pavur, R., \& Kulkarni, S. (2019). Cognitive biases resulting from the representativeness heuristic in operations management: An experimental investigation. Psychology Research and Behavior Management, 12, 263-276. https:// doi.org/10.2147/PRBM.S193092

2. Anderson, J. C., \& Gerbing, D. W. (1984). The Effect of Sampling Error on Convergence, Improper Solutions, and Goodnessof-Fit Indices for Maximum Likelihood Confirmatory Factor Analysis. Psychometrika, 49, 155-173. https://doi.org/10.1007/ BF02294170

3. Bakar, S., \& Yi, A. N. C. (2016). The impact of psychological factors on investors' decision making in the Malaysian stock market: a case of Klang Valley and Pahang. Procedia Economics and Finance, 35, 319-328. https://doi.org/10.1016/S22125671(16)00040-X

4. Bandura, A. (1977). Self-efficacy: toward a unifying theory of behavioral change. Psychological Review, 84(2), 191215. https://doi. org/10.1037/0033-295X.84.2.191

5. Bandura, A. (1982). Self-efficacy mechanism in human agency. American Psychologist, 37(2), 122147. https://doi.org/10.1037/0003066X.37.2.122

6. Barnes Jr, J. H. (1984). Cognitive biases and their impact on strategic planning. Strategic Management Journal, 5(2), 129137. https://doi.org/10.1002/ smj.4250050204

7. Bartha, P. (2013). Analogy and analogical reasoning. Stanford Encyclopedia of Philosophy. Retrieved from https://plato. stanford.edu/entries/reasoninganalogy/

8. Bonn, I., \& Fisher, J. (2011) Sustainability: the missing ingredient in strategy. Journal of Business Strategy, 32(1), 5-14. https://doi. org/10.1108/02756661111100274

9. Busenitz, L. W., \& Barney, J. B. (1997). Differences between entrepreneurs and managers in large organizations: Biases and heuristics in strategic decision-making. Journal of Business Venturing, 12(1), 9-30. https://doi.org/10.1016/S08839026(96)00003-1

10. Chung, E., \& McLarney, C. (1999). When giants collide: strategic analysis and application. Management Decision, 37(3), 233-248. https://doi. org/10.1108/00251749910264479

11. Corder, G. W., \& Foreman, D. I. (2009). Non-parametric Statistics for Non-Statisticians: A Step-by-Step Approach. John Wiley \& Sons. https://doi. org/10.1002/9781118165881

12. Das, T. K., \& Teng, B. S. (1999). Cognitive biases and strategic decision processes: An integrative perspective. Journal of Management Studies, 36(6), 757 778. https://doi.org/10.1111/14676486.00157

13. Dube-Rioux, L., \& Russo, J. E. (1988). An availability bias in professional judgment. Journal of Behavioral Decision Making, 1(4), 223-237. https://doi.org/10.1002/ bdm.3960010403

14. Gigerenzer, G., \& Goldstein, D. G. (1996). Reasoning the fast and frugal way: models of bounded rationality. Psychological Review, 103(4), 650-669. https://doi. org/10.1037/0033-295X.103.4.650

15. Hill, C. W., Jones, G. R., \& Schilling, M. A. (2014). Strategic management: Theory \& cases: An integrated approach. Cengage Learning. Retrieved from https:// www.fedeeh.org/sites/default/ files/webform/pdf-strategic-management-theory-an-integratedapproach-charles-w-1-hill-garethr-jones-melissa-a-schilling-pdfdownload-free-book-3694d74.pdf

16. Knight, P. A., \& Nadel, J. I. (1986) Humility revisited: Self-esteem, information search, and policy consistency. Organizational Behavior and Human Decision Processes, 38(2), 196-206. https://doi.org/10.1016/07495978(86)90016-6

17. Kyriazos, T. A. (2018). Applied psychometrics: sample size and sample power considerations in factor analysis (EFA, CFA) 
and SEM in general. Psychology, 9(8), 2207-2230. https://doi. org/10.4236/psych.2018.98126

18. Levine, M. (1971). Hypothesis theory and nonlearning despite ideal S-R-reinforcement contingencies. Psychological Review, 78(2), 130-140. https://doi. org/10.1037/h0030647

19. Markovitch, D. G., Huang, D., Peters, L., Phani, B. V., Philip, D., \& Tracy, W. (2014). Escalation of commitment in entrepreneurshipminded groups. International Journal of Entrepreneurial Behavior \& Research, 20(4), 302323. https://doi.org/10.1108/ IJEBR-08-2013-0127

20. Meissner, P., \& Wulf, T. (2017). The effect of cognitive diversity on the illusion of control bias in strategic decisions: An experimental investigation. European Management Journal, 35(4), 430-439. https://doi. org/10.1016/j.emj.2016.12.004

21. Miller, D. (1990). The Icarus Paradox. HarperCollins, New York, NY.

22. Mintzberg, H. (1973). Strategymaking in three modes. California Management Review, 16(2), 44-53. http://dx.doi. org/10.2307/41164491

23. Montibeller, G., \& Von Winterfeldt, D. (2015). Cognitive and motivational biases in decision and risk analysis. Risk Analysis, 35(7), 1230-1251. https://doi. org/10.1111/risa.12360

24. Murata, A., Nakamura, T., \& Karwowski, W. (2015). Influence of cognitive biases in distorting decision making and leading to critical unfavorable incidents. Safety, 1(1), 44-58. https://doi. org/10.3390/safety 1010044

25. Nooraie, M. (2012). Factors influencing strategic decisionmaking processes. International Journal of Academic Research in Business and Social Sciences, 2(7), 405-429. Retrieved from https:// silo.tips/download/factors-influencing-strategic-decision-makingprocesses

26. Nouri, P., Imanipour, N., Talebi, K., \& Zali, M. (2018). Most common heuristics and biases in nascent entrepreneurs' marketing behavior. Journal of Small Business \& Entrepreneurship, 30(6), 451472. https://doi.org/10.1080/08276 331.2018 .1427406

27. Quinn, J. B. (1978). Strategic change: logical incrementalism. Sloan Management Review, 20(1), 7-21.

28. Schwarz, N., Bless, H., Strack, F., Klumpp, G., Rittenauer-Schatka, H., \& Simons, A. (1991). Ease of retrieval as information: another look at the availability heuristic. Journal of Personality and Social Psychology, 61(2), 195-202. https://doi.org/10.1037/00223514.61.2.195

29. Schwenk, C. R. (1984). Cognitive simplification processes in strategic decision-making. Strategic Management Journal, 5(2), 111-128. https://doi. org/10.1002/smj.4250050203

30. Schwenk, C. R. (1988). The cognitive perspective on strategic decision making. Journal of Management Studies, 25(1), 41-55. https://doi. org/10.1111/j.1467-6486.1988. tb00021.x

31. Seppälä, A. (2009). Behavioral biases of investment advisorsThe effect of overconfidence and hindsight bias (Master's Thesis). Retrieved from https://core.ac.uk/ download/pdf/80700137.pdf

32. Sharma, R., Mithas, S., \& Kankanhalli, A. (2014). Transforming decision-making processes: a research agenda for understanding the impact of business analytics on organizations. European Journal of Information Systems, 23(4), 433-441. https://doi. org/10.1057/ejis.2014.17

33. Staw, B. M. (1981). The escalation of commitment to a course of action. Academy of Management Review, 6(4), 577-587. https://doi. org/10.5465/amr.1981.4285694

34. Tversky, A., \& Kahneman, D. (1974). Judgment under uncertainty: Heuristics and biases. Science, 185(4157), 1124-1131. https://doi.org/10.1126/science.185.4157.1124
35. Wheelen, T. L., Hunger, J. D., Hoffman, A. N., \& Bamford, C. E. (2010). Strategic management and business policy. Upper Saddle River, NJ: Prentice Hall.

36. Whyte, G., Saks, A. M., \& Hook, S. (1997). When success breeds failure: The role of self-efficacy in escalating commitment to a losing course of action. Journal of Organizational Behavior, 18(5), 415-432. https:// doi.org/10.1002/(SICI)10991379(199709)18:5<415::AIDJOB813>3.0.CO;2-G

37. Xue, Y., Sun, S., Zhang, P., \& Meng, T. (2015). Impact of cognitive bias on improvised decision-makers' risk behavior: an analysis based on the mediating effect of expected revenue and risk perception. Management Science and Engineering, 9(2), 31-42. http:// dx.doi.org/10.3968/6843

38. Zuckerman, M., Knee, C. R., Kieffer, S. C., Rawsthome, L., \& Bruce, L. M. (1996). Beliefs m Realistic and Unrealistic Control: Assessment and Implications. Journal of Personality, 64(2), 435-464. https://doi. org/10.1111/j.1467-6494.1996. tb00517.x 